\title{
Evidence of pollen features and peroxidase isozymes in their morphological complexity of ten local cultivars of sweet potato from Indonesia
}

\author{
SURANTO ${ }^{1,2, \boldsymbol{v}}$, DWI WAHYUNI ${ }^{2,3}$, EDY PURWANTO $^{4}$ \\ ${ }^{1}$ Program of Biology, Faculty of Mathematics and Natural Sciences, Universitas Sebelas Maret. Jl. Ir. Sutami 36A, Surakarta 57126, Central Java, \\ Indonesia. Tel./fax.: +62-271-663375, ”email: surantoak@yahoo.com \\ ${ }_{2}^{2}$ Program of Bioscience, Graduate Program, Universitas Sebelas Maret. J1. Ir. Sutami No. 36A Kentingan, Surakarta, 57126, Central Java, Indonesia \\ ${ }_{3}^{3}$ Institut Ilmu Kesehatan Bhakti Wiyata. Jl. KH Wahid Hasyim No. 65, Kota Kediri 64114, East Java, Indonesia \\ ${ }^{4}$ Departement of Agrotechnology, Faculty of Agriculture, Universitas Sebelas Maret. Jl. Ir. Sutami 36A, Surakarta 57126, Central Java, Indonesia
}

Manuscript received: 24 May 2019. Revision accepted: 15 August 2019.

\begin{abstract}
Suranto, Wahyuni D, Edy Purwanto E. 2019. Evidence of pollen features and peroxidase isozymes in their morphological complexity of ten local cultivars of sweet potato from Indonesia. Biodiversitas 20: 2511-2518. Sweet potato (Ipomoea batatas Lam) has been recorded to have many cultivars and variations in the morphological characters not only for the leaves but also for the tubers. Sweet potatoes had economically significant role, especially as an additional food due to its high content of carbohydrate and other nutrient values. In order to test whether the morphological variation in this species was also expressed at the micro character; such as pollen morphology and enzyme activity, ten sweet potato cultivars were used in this study. The morphological characters such as shape and structure of the pollen features were examined using Scanning Electron Microscopy (SEM). Accordingly, Polyacrylamide Gel Electrophoresis (PAGE) was used to look-at the banding pattern of peroxidase isozymes. Morphological characters of leaves, flowers, and tuber were observed qualitatively both for the typical shape and colors. More detail of flower shapes was drown manually especially their petal edges. The results showed that there was variation among the ten sweet potato cultivars confirmed not only on their morphological characters but also the isozyme banding patterns of ten cultivars tested. At least, two cultivar Antin 3 and Papua Solossa had uniques characters especially the purple stem and yellow tuber and dark skin on the tuber, respectively. In addition, the structural analysis of pollen showed that Beta 1 cultivar has very large pollen; 116,50 $\mu \mathrm{m}$ (axis polar) and the contour surface of exine pollen was concave with the aperture shape and ornamentation were prolate spheroidal and echinate respectively. This unique character was also shown by its peroxidase isozyme bands. Eleven bands of leaf and 13 bands of stem samples were detected respectively. The typical Rf values of $0.31,0.48$ and 0.41 were detected for the leaf, while for stem samples were $0.14,0.20$ and 0.26 . The Beta 1 cultivar showed very thick bands in between Rf values of 0.13 and 0.26 . Meanwhile, the unique band pattern of Papua Salosa was the absence of band at 0.38 .
\end{abstract}

Keywords: Cultivar, Ipomoea batatas, peroxidase, pollen features

\section{INTRODUCTION}

Sweet potatoes (Ipomoea batatas L) had been recorded as one of the very potential cultivated plant because of the usefulness of this plant to the human consumption, especially as the functional food (Maurigue et al. 2007; Ginting et al. 2012). I. batatas is one out of 1650 species in the family Convolvulaceae and these species of plants were grouped under 58 genera (Cheng et al. 1995). These sweet potatoes were planted widely not only on the tropical area, but also on the temperate environments such as Japan and South Korea. The diversity of sweet potatoes cultivars was found evident not only on the leaf and flower characters but also on their tuber and nutrient content (Away et al. 2013). In addition, Suda et al. (1992) noted that morphological variation on the stem, such as color and diameters as well as the length of internodes were documented. Accordingly, the flower is interesting to be intensively studied because of the very attractive color and shape as well as the pollen feature. Study about plant morphology as well as peroxidase activity of sweet potatoes had been widely conducted (Wilson 1988; Mudnan 1999; Suratman et al.
2000; Supadmi 2009; Kim et al. 2010; Jamshidi and Samira 2011; Ginting et al. 2012; Wahyuni and Wargiono 2013; Diao et al. 2014)

Meanwhile, characterization of pollen morphology in sweet potato cultivars at our laboratory was at the first time, but other species of Convolvulvaceae plants had been conducted intensively, for example, (Kodela (2006) who worked with some rainforest taxa in New South WalesAustralia, Solanum (Solanaceae) (Lashin 2011) and Bauhinia (Caesalpiniaceae) (Tidkel et al. 2012). Other studies using pollen samples employing SEM were conducted by Rajukar et al. (2011). They found that three species of Ipomoea showed blunt spine and only I.palmata reveals pointed spine. It was interesting to note that, when the number of spine increases, the aperture size tend to reduce (I. aquatica and I. triloba). This study suggests that successive form of evolutionary pollen pattern had occurred from tricolpate to pantoporate. Similar work using I. aquatica shows that this plant has aperture of periporate or pantofreme in arrangement (Adekansi 2009). At least, some pollen characters such as size and apertures and polar axis, as well as equatorial and diametre of pollen were 
quite often useful in assisting taxonomists making decision whether certain cultivars should be grouped at the same genus or species (Veasey et al. 2007). Confirmation about the status of plant cultivars within certain species usually even better when more data of genetic and secondary metabolism were used (Li et al. 2009; Troung, et al. 2007; Widiyanti et al. 2008; Purnobasuki et al. 2014; Hadiati and Sukmadjaja 2002).

The activity of an enzyme will result in very specific isozyme banding patterns. Twelve (12) bands of esterase isozymes with $\mathrm{Rf}$ values ranged from 0.08 to 0.95 were detected by Pitoyo et al (2018) in taro (Colocasia esculenta) accessions from southeastern part of Central Java. Meanwhile 8 bands of peroxidase isozymes detected with $\mathrm{Rf}$ values from 0.08 to 0.13 . Both enzyme systems showed 20 banding patterns. It is considered that these isozymes data were recorded to be one of the most often used in conjunction with group of plant differentiation among taro accession (Smith and Balamarugar (2014) and Kumar et al. 2015). Similar studies using the same two enzyme systems were also conducted by Hidayati et al (2018) employing the leaf samples of Cucurbita moschata. They recorded 10 bands of peroxidase isozyme and 8 isozymes banding pattern of esterase. The $10 \mathrm{Rf}$ values were in between 0.050 and 0.458 . Accordingly, 8 bands were noted in which the position of those bands ranging from 0.015 to 0.600 . In this study, peroxidase isozyme band was chosen to prove whether ten cultivars of sweet potatoes have the same banding pattern or difference.

Another reason for using this enzyme is due to the fact that this approach was very easy and simple to do as well as it is quite cheap in running this experiment. Besides, this oxidase enzyme had been recorded to have very high intensity on the plant organ especially during wounding time (Agrios 2005; Yanti 2011). This occurrence may have been correlation with defense mechanism of the plant, particularly when they grow under unfavorable environmental condition. This phenomenon was partly explained by Suranto et al. (2017) in detecting rice infected virus. These studies were conducted to have a look at whether variation of morphological character of ten local sweet potatoes would be shown also on their appearance of pollen morphology and also the isozyme banding patterns of peroxidase.

\section{MATERIALS AND METHODS}

\section{Sample collection}

Plant samples of ten cultivars were kindly provided by Yudi Widodo of the Research Centre of Horticultural Plants (RHCP) from Kendalpayak of Malang District, East Java, Indonesia. In order to make sure that all samples used in this experiment were in the same maturity and development, the observation and examination on the shape of leaves and flowers as well as the pollen morphology were conducted during anthesis. Accordingly, the tubers of all ten cultivated were also harvested at the same condition namely at the end of planting time, to have a look at the color and shapes of I. batatas tubers. Ten individual plants of each cultivar were used in this experiment.

\section{Morphological observation}

To look at the morphological variations of each cultivar the leaves, flowers, and tubers were used. We only choose these characters, due to fact that most of these species features were very easily recognized and characterized by their morphological appearances. Although, several other traits (e.g; stem and seeds) may quite be important to be employed, but in this time being we prefer the only those traits used due to the common attractive outer features of this species, and this in order to make sure that more data would still be available for the near future experiments. Total of ten individual plants of each cultivar was observed and the type of each morphological features was presented at Figure 1. For the ornamentation of petal appearances hand drawing of each flower was conducted to have a look whether any difference between them; and these pictures were put below the pictures of real flower. Accordingly, to look at the different color of ten cultivar tubers, two to three tubers of each cultivar was crossed cut and the skin color of each cultivar tuber was recorded. All the above morphological characters were analyzed qualitatively. These morphological features particularly the leaves were further examined their leaf apices, leaf shape, leaf margins, leaf bases, and leaf color. Meanwhile, for the flower traits were color, shape and petal margins. All of the above character were descriptively recorded.

\section{Pollen observation}

This experiment was conducted at Universitas Negeri Malang (UM), Malang from April to May 2014. The procedures for preparing pollen for observation in this experiment was conducted according to Arrijani (2003). For each individual sample of ten sweet potato cultivars have been selected from every single fresh flower aged 4-5 months. The harvested pollens were then put in every single vial bottle containing $70 \%$ alcohol. The pollen of each ten cultivars was then picked up using needle and placed on specimen holder (1:1 cm in high and diameter) by using double-sided carbon tape, and then the pollen's holder was put on spatter coater for further gold-palladium coated treatment. The pollen features such as spina length were examined under SEM (Merk FEI type Inspect S50), employing magnificent of 2500 times according to the procedures of manufacture's recommendation.

\section{Electrophoresis of peroxidase isozymes}

Polyacrylamide gel electrophoresis (PAGE) was used to examine the activity of peroxidase isozyme. The isozyme sample was taken from the third leaf of each ten cultivars tested during anthesis and the stem samples were also taken from third internodes from the top. The lamina leaves and stems were examined separately. Procedures of preparing buffer solution, gel preparation, leaf and stem samples extraction, electrophoresis condition as well as the staining solution of peroxidase were conducted according to Mill and Crowden (1968) and Suranto (2001) with a bit of modification; particularly the amount of samples and the 
volume of extraction buffer. We used $25 \mathrm{mg}$ of sample instead of $10 \mathrm{mg}$, and $500 \mu \mathrm{L}$ of extraction buffer solution instead of $200 \mu \mathrm{L}$. The resulted peroxidase isozymes banding pattern were then calculated for their $\mathrm{Rf}$ values using formula of Todaria et al. (1983). All activities of electrophoretic isozyme of peroxidase were run at our laboratory of molecular biology-FMIPA UNS, from June to August 2014. The data obtained were then analyzed descriptively by looking at the presence or absence of the bands for the samples tested. Zymyrans of peroxidase isozymes were constructed based on the resulted $\mathrm{Rf}$ values of each cultivar sampled. The typical bands and very unique band of each cultivar were described qualitatively.

\section{RESULTS AND DISCUSSION}

\section{Morphological characters}

Variation of leaves, tubers and petal shapes of sweet potato (Ipomea batatas (L.) Lam) as seen in Figure 1, variation of lamina leaves was recorded. At last three groups of lamina were observed. Three cultivars of Antin $(1=$ Antin $1 ; 2=$ Antin 2; 3= Antin 3) were to have similar lamina shape of three foliate typical lamina as the first group, meanwhile for the second group; 4 (Beta 1), 6 (Kidal), 9 (Sawentar) were characterized by the oblate leaves. In addition, the third group consisted of, three cultivars 5 (Beta 2), 7 (Papua Salosa) and 8 (Sari) were detected to have pentalobus leaves. The remaining cultivars of Sukuh (10) tended to have very similar features as the second group, but in certain cases the size usually a bit longer and the venal branches were more clear.

In general, the basic lamina shape of sweet potato was cordatus, with flat at leaf edges and the leaf tip was attenuates but notched leaf was found at the bottom. These could be seen at variants number 4, 6, 9 and 10. The deeper notched leaves at the bottom were found at number 9 and 10 respectively. This basic variation of lamina leaves of sweet potatoes was confirmed particularly at the edged leaves. These variations were observed at variants number 1 and 3 in which their leaf edges were trilobus, meanwhile, the pentalobus have occurred at number 2, 5, 7 and 8 . Furthermore, deeper notched leaf edge was found at no 7 which tend to be palmatus leaves.

These qualitative morphological character has been considered by Aguoru et al. 2015 would be more useful in helping taxonomists to make decision when further detail of crossed section leaves such as epidermal characters e.g: stomatal types, stomatal index, and number of epidermal cells were also employed. Besides, other characters such as stem diameters, root size, and plant height were also could be used to support the taxonomist data. By using all the above morphological appearances, it may be interesting to note that ten varieties of Ipomea batatas studied could contribute to understanding evolutionary relationships among this species (Eserman et al 2014). These leaf variations were in accordance with the petal shapes.

The corolla of sweet potato flower was usually to have trumpet shaped, with corolla tube at lateral parts and purple in the middle one. Total number of five petals with attached each other and pale white was found as the type of sweet potato flowers. The variants numbers 4 and 6 had deeper notched petals as compared to others which usually only have mild notched petals. The appearance of flower color and shapes were in contrast with the tuber characters. This species of Convolvulaceae can be recognized by their funnel-shaped radially symmetrical corolla with floral formula for the family has 5 sepals, 5 fused petals, 5 epipetalous stamens and a 2 part syncarpous and superior gynoecium (Sahu and Gupta 2015). Despite the fact that flower features were not only the petal, therefore it may be crucial to consider that this character particularly the flower color would be significantly important in understanding of speciation of this species (Smith et al. 2010). By looking at the flower color, studying of occurring transition of blue to red flower could be conducted intensively (Eserman et al. 2014). In addition, they argued that the occurrence of transition of blue/purple color of petals to the red could be due to drastically reduction of in production of anthocyanin biosynthetic pathway $\mathrm{F} 3$ 'H.

There were three different basic colors recorded. The light to dark purples was found from 1, 3 and 2 cultivars, respectively. Meanwhile, the basic yellow colors ranging from pale yellow to orange were observed on the cultivars; $9,8,6,5,7$ and 4. And the only white tuber was recorded for cultivar number 10. These varied tuber colors were also shown in their tuber skins. Another tuber feature which is interested to be recorded was the tuber form. At least two basic forms were identified. The round and long shapes were recorded, although in between that shapes were also noted. The real long shapes were only found for Antin 3 and Beta 1. Meanwhile, the intermediate shapes were observed at Antin $1 \& 2$ and Papua Salosa. The divers forms of tubers of sweet potato were also shown but these forms are usually not attractive to be studied if compared to the tuber colors. (Rose and Vasanthakaalam 2011, Tsakama et al. 2010).

\section{Pollen morphology}

SEM showed that the ten sweet potato cultivars had variation in their spina length. Antin 1 had the longest spina (ranging from $7.60 \mu \mathrm{m}$ to $10.98 \mu \mathrm{m}$ ), while the shortest one $(5.04 \mu \mathrm{m})$ was shown by "Sawentar" cultivar. The total pollen volume of all the cultivars could be classified as large pollen, except the Beta 1 cultivar had very large one. The $\mathrm{P} / \mathrm{E}$ index of these sweet potato cultivars varied between 1.00 and 1.14 in which the prolate spheroidal was the common shape. In addition, the total number of aperture was recorded as "polyapertures" with "porate type" and the position was "ponto".

The detailed morphology of pollen shown on the ornamentation and radical symmetry of the exin was Ekinat. It is interesting to note that spina shape of the ten sweet potatoes cultivars was bottle shape with rounded shape on the top and getting wider at the middle part and rounded at the bottom part. Beta 1 had the volume as the longest of polar axis (P) $116.5 \mu \mathrm{m}$ and the contour of exine was concave when observed equatorially. This unique picture was not only observed once. A number of trials conducted to convince the abnormality of the exine surface 
yielded the same results. This little phenomenon of pollen distinctiveness of Beta 1 cultivar was quite crucial to be tested further in order to make sure whether this would have influence in its morphological traits.

In general, the ten sweet potato cultivars had varied spina length ranging from 5.04 to $10.98 \mu \mathrm{m}$. The longest was recorded at the Antin 1 cultivar $(9.76-10.9 \mu \mathrm{m})$, while the shortest $(5.04-6.95 \mu \mathrm{m})$ was found in Sawentar. It is interesting to find that pollen of all ten sweet potato cultivars had been classified as 'large size', except for Beta 1 cultivar that was classified as very large. The variation of $\mathrm{P} / \mathrm{E}$ Index with the range between 1.00 and 1.13 , with the shape of pollen was prolate spheroidal. In addition, the total number of aperture was poly, and the type of pollen was porate with the ponto position, semi radial and exine ornamentation were echinate. Especially Beta 1. their size of the pollen were found to be very large one, and only this cultivar to have that size compared to other 9 cultivars.

Table 1. Pollen morphological characters of ten sweet potato cultivars

\begin{tabular}{|c|c|c|c|c|c|c|c|c|c|c|}
\hline \multirow[b]{2}{*}{ Cultivars } & \multicolumn{2}{|c|}{ Length $(\mu \mathrm{m})$} & \multirow[b]{2}{*}{ Size } & \multirow{2}{*}{$\begin{array}{c}\text { Equatorial } \\
\text { Diameter } \\
(\mathbf{E})(\mu \mathrm{m})\end{array}$} & \multirow[b]{2}{*}{$\begin{array}{c}\mathbf{P} / \mathbf{E} \\
\text { Index }\end{array}$} & \multirow[b]{2}{*}{ Shape } & \multicolumn{3}{|c|}{ Aperturer } & \multirow[b]{2}{*}{$\begin{array}{c}\text { Ornamen- } \\
\text { tation }\end{array}$} \\
\hline & Spine & $\begin{array}{l}\text { Polar } \\
\text { axis (P) }\end{array}$ & & & & & Total & Type & Position & \\
\hline Antin 1 & $9.76-0.98$ & 92.90 & Large & 81.60 & 1.13 & Prolate spheroidal & Poly & Porate & Panto & Echinate \\
\hline Antin 2 & 7 & 95.20 & Large & & & Prolate spheroidal & Poly & & Panto & Echinate \\
\hline Antin 3 & $42-8$ & 93. & Large & & & Prolate spheroidal & Poly & Porat & Panto & Echinate \\
\hline Beta 1 & $34-8.37$ & 116 & Very large & & & Prolate spheroidal & Poly & Porat & Panto & Ekinat \\
\hline Beta 2 & $3-7.56$ & 89.16 & Large & 78. & 1.1 & Prolate spheroidal & Poly & Porate & Panto & Echinate \\
\hline Kidal & $60-7.03$ & 88.84 & arge & 8 & 1.06 & Prolate spher & Poly & Porate & Panto & Echinate \\
\hline Papua solossa & $5.16-6.98$ & 91.84 & Large & 81.32 & 1.13 & Prolate spheroidal & Poly & Porate & Panto & Echinate \\
\hline Sari & $7.26-8.23$ & 98.33 & Large & 93.4 & 1.05 & Prolate spheroidal & Poly & Porate & Panto & Echinate \\
\hline Sawentar & 5.04-6.95 & 85.39 & Large & 83.15 & 1.03 & Prolate spheroidal & Poly & Porate & Panto & Echinate \\
\hline Sukuh & $6.57-7.21$ & 90.55 & Large & 85.65 & 1.06 & Prolate spheroidal & Poly & Porate & Panto & Echinate \\
\hline
\end{tabular}
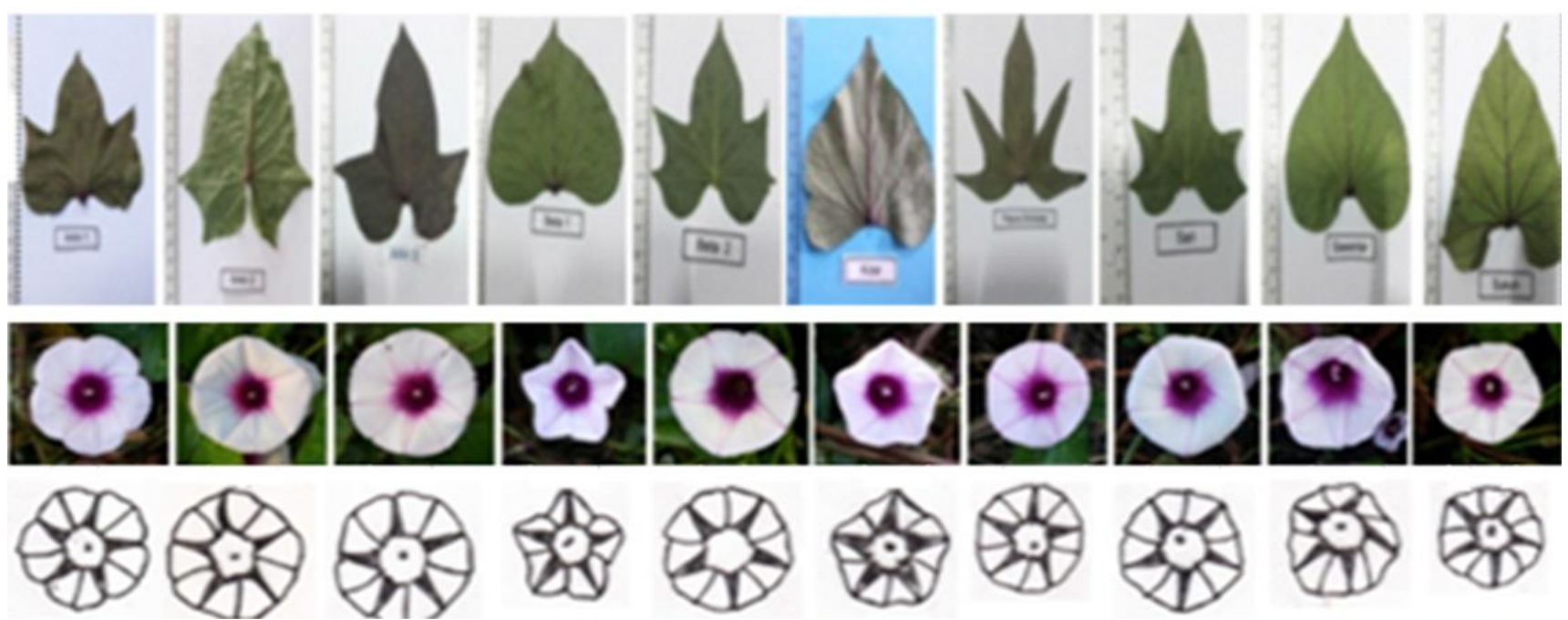

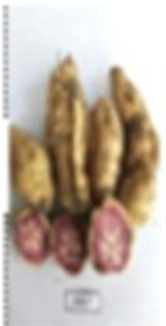

1

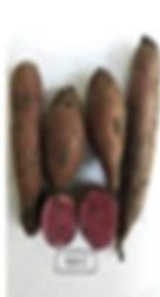

2

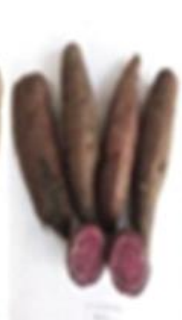

3

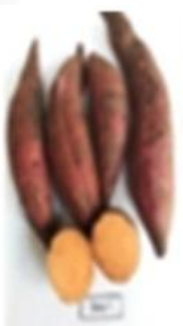

4

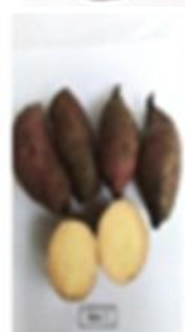

5

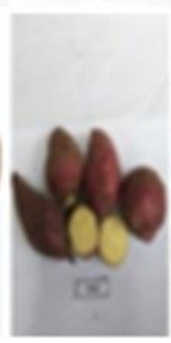

6

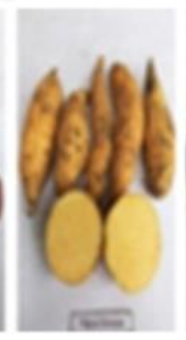

7

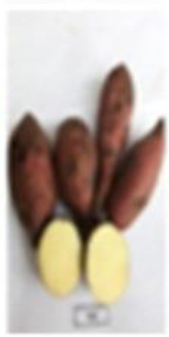

8

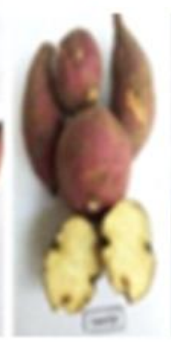

9

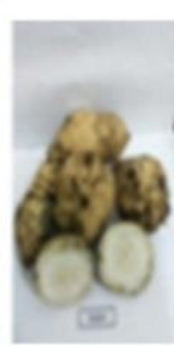

10

Figure 1. Morphological appearances of ten cultivars of sweet potatoes; tubers, leaves, and flowers. Number 1 to 10 indicate the local cultivar names: 1. Antin 1, 2. Antin 2, 3. Antin 3, 4. Beta 1, 5. Beta 2, 6. Kidal, 7. Papua Salosa, 8. Sari, 9. Sawentar, 10. Sukuh 
A
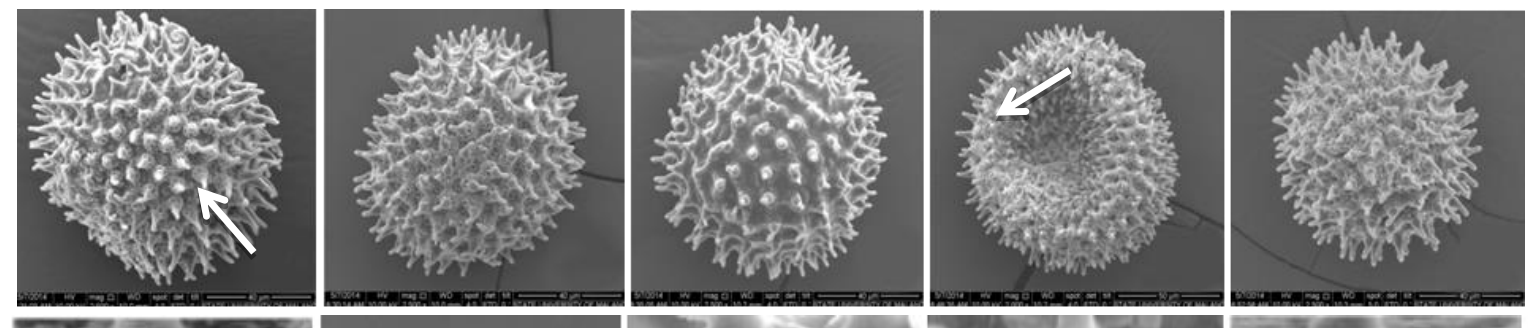

B
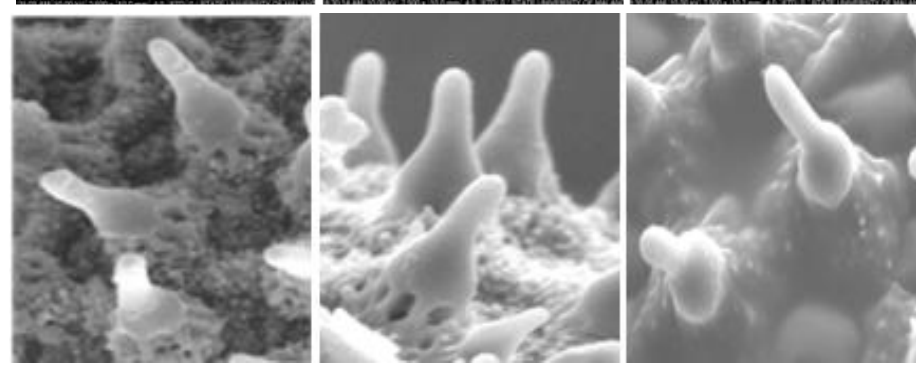

3

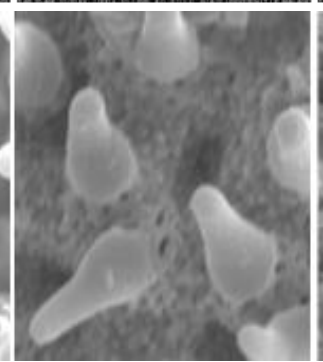

4

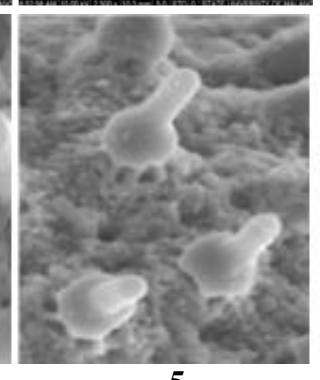

A
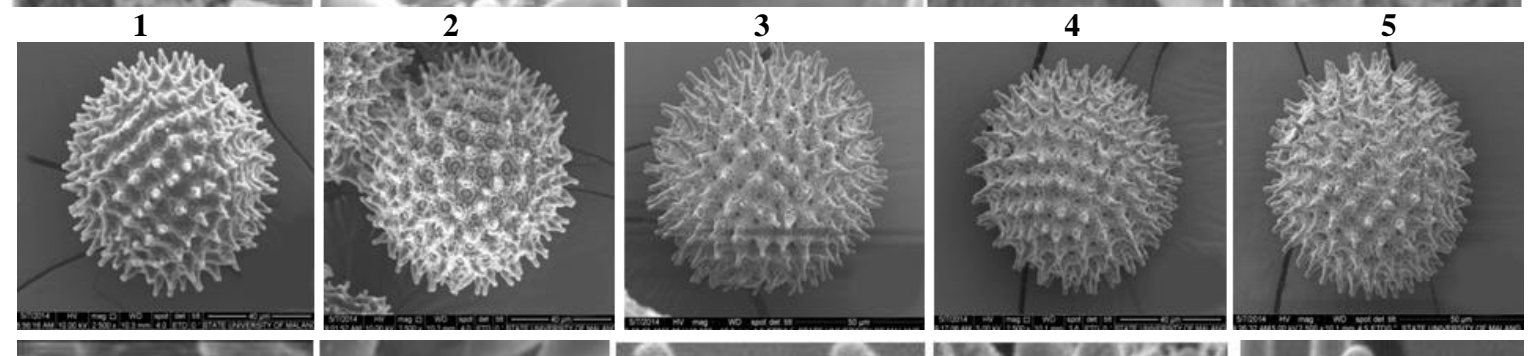

B

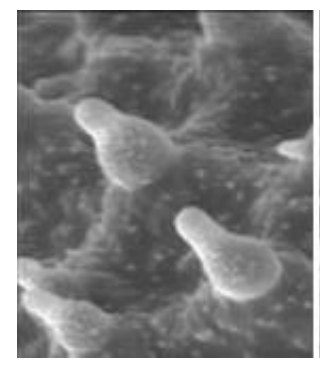

6

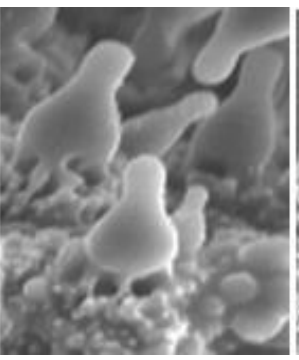

7

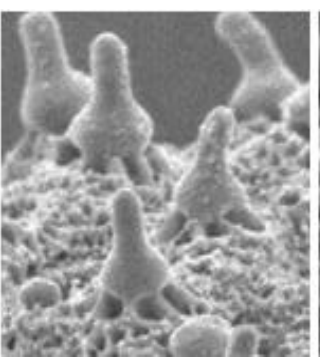

8

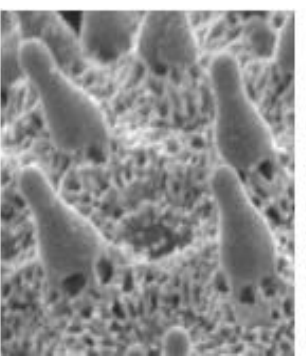

9

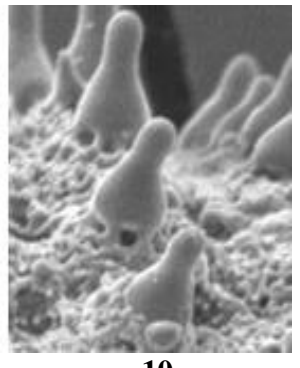

10

Figure 2. Pollen morphology (A) and spina shapes (B) under SEM (Scanning Electron Microscope). Sweet potato cultivars: 1. Antin 1, 2. Antin 2, 3. Antin 3, 4. Beta 1, 5. Beta 2, 6. Kidal, 7. Papua Salosa, 8. Sari, 9. Sawentar, 10. Sukuh

Another interesting feature of these cultivars was shown by Papua Salosa, in which the species length was only 5.16-6.98 $\mu \mathrm{m}$, and this was recorded as the shortest. But their composition of polar axis $(91.84 \mu \mathrm{m})$ and equatorial diameter $(81.32 \mu \mathrm{m})$ yielded index of $\mathrm{P} / \mathrm{E}$ to be the same as shown by Antin 1 which was recorded as the longest spine of these 10 cultivars. Despite the above facts, we recorded that the biggest index of P/E was Beta $2(1.14 \mu \mathrm{m})$ and conversely, the smallest was found from Antin 3 cultivar $(1.00 \mu \mathrm{m})$.

The examination of pollen aperture of ten cultivars tested show the same pictures; all variants to have total number of apertures was poly, with porate aperture type and panto position and the ornamentation was echinate. This result was in accordance with Agashe and Caulton (2009) and Edtman (1952), and also confirmed by Purnobasuki et.al. (2014) and Widiyanti et.al. (2008) in which the shape of pollen features within one species usually to have the same characters. In addition, Esermen et al (2014) noted that spiny pollen of species within
Ipomea was typical features of this varietal I.batatas. Although the above is true, it is quite unique appearances of the pollen shape especially the contour which was observed in the Beta 1. In all ten pollen cultivar had the pollen contour of circular, but only this Beta 1 had the concave one. This unique feature of this cultivar of Beta 1 had been the target of further examination using electrophoretic isozyme.

\section{Peroxidase isozyme}

Peroxidase has been classified in the oxidoreductase and this enzyme can be detected easily due to its high stability and ability to use a number of substrate as hydrogen donor (Cahyarini et al. 2004). As seen in Figure 3 , thirteen bands of peroxidase isozymes have been produced. All the $13 \mathrm{Rf}$ values were $0 ; 0.08 ; 0.14 ; 0.20$; $0.26 ; 0.38 ; 0.43 ; 0.45 ; 0.48 ; 0.51 ; 0.65 ; 0.74$; and 0.77 . Based on the appearance of the bands, Beta 1 and Beta 2, as well as Papua Salosa cultivars, were qualitatively having different bands and total number of 6,10 and 9 bands were 
respectively produced, compared to the other seven cultivars. The undetected band of Rf 0.38 at cultivars Beta 1 and Papua Salosa indicated that these two sweet potato cultivars were very unique, although the other cultivars usually had those bands.

The uniqueness of Papua Salosa cultivar had been shown by the absence of band at 0.38 and the presence of band at Rf value of 0.43 , respectively (Figure 3 ). Another uniqueness of this for Beta 2 cultivar was recorded because this cultivar had band at Rf 0.45 in which the other 9 (nine) cultivars didn't have any. The thickness of bands of Beta 1 (Rf: 0.14 and 0.20) and Beta 2 (Rf 0.0) indicated that enzyme activity at both cultivars was high. Conversely, very thin bands at position of $0.51,0.65,0.74$ and 0.75 of Papua Salosa had been implicated to have very weak enzyme activity. This enzyme activity had been recorded by Hengky (1995) in which, the thicks band had been an indication of very active enzyme, meanwhile the thin band had been recorded as very weak activity of the enzyme. Alnopri et al. (2009) assumed that the thick bands produced by certain cultivars had been implemented to have high degree of resistance to diseases. This phenomenon had been shown by Souza et al. (2003) in corn plants inoculated with maize dwarf mosaic virus (MDMV). The high activity of peroxidase had been considered very useful in preventing the virus spread to the cell wall. Accordingly, the very thin bands on the Papua Salosa had been assumed to indicate this cultivar's susceptibility to the sweet potato weevil, Cylas formicarius (Balitkabi 2012).

The resulted bands produced by electrophoretic isozymes of peroxidase employing the leaf samples were not much different compared to those from stem samples. The eleven (11) bands were detected as Rf values of: 0; $0.13 ; 0.17 ; 0.22 ; 0.26 ; 0.31 ; 0.35 ; 0.40 ; 0.41 ; 0.57$ and
0.95.The very thick bands of $0 ; 0.17$ and 0.22 were recorded to be the characteristic of Beta 1 cultivar, meanwhile, the Kidal cultivar has been characterized by the presence of bands values at $\mathrm{Rf} 0.22$ and Sukuh cultivar (0), respectively. The unique bands of this leaf sample were again shown by Papua Salosa cultivar, which showed no band at Rf: 0.13. This very specific characters of peroxidase isozyme were also supported by morphological appearances. Nandariyah (2008) recorded that the appearance of Salacca edulis cultivar in their morphological character was also in accordance with their genetic data. In addition, Budoyo (2010), reported that more bands were observed at sweet potato cultivars which usually had higher carbohydrate contents. Although, Budoyo's (2010) finding was not exactly the same this our experiment, it is interesting to note that both samples collected from the leaves and stems had relatively number of bands of the peroxidase isozymes; 13 and 11 bands respectively. This means that using this enzyme activity, ten local sweet potatoes can be distinguished. Recent studies dealing with peroxidase isozyme had been conducted by Suranto et al. (2017), who noted that not only the total number of isozyme bands was useful in distinguishing the difference between the healthy and the virus-infected plants, but this enzyme activity on both samples was also able to compare, especially through their band thickness, between the healthy and the diseased plants. Other interesting results of the above two isozymes were reported by Hidayati et al (2018) dealing with Cucurbita moschata at different altitudes. They note that 10 of peroxidase isozymes and 8 of esterase isozymes were recorded. The thickness band of peroxidase isozymes was found at higher altitudes rather than the lower ones. This phenomenon was also recorded at the isozymes of esterase.
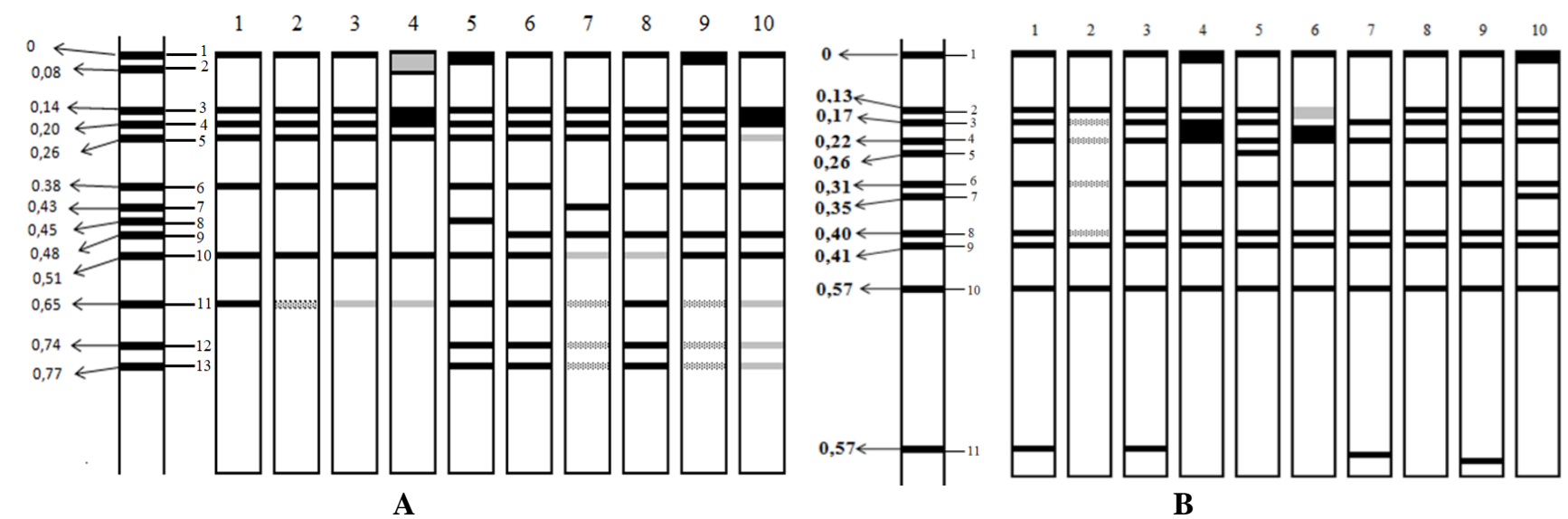

B

Figure 3. Zymograms of peroxidase isozymes of ten sweet potato cultivars tested: stem samples (A) and leaf samples (B). The Rf value of each sample was presented on the left side of each zymogram. Number 1 to 10 indicates the name of the cultivar: 1 . Antin 1,2 . Antin 2, 3. Antin 3, 4. Beta 1, 5. Beta 2, 6. Kidal, 7. Papua Salosa, 8. Sari, 9. Sawentar, 10. Sukuh 


\section{Taxonomic significance}

Studies about the use of pollen features especially those dealing with about 170 species belonging to the 30 genera of Convolvulaceae from India had been investigated comprehensively by Sengupta (1972). This family was characterized by number and distribution of aperture of the pollen type. The basic type of pollen features of this family to be the tricolpate type. This type of specialization further resulted in other apertural types such as pentacolpate, hexacolpate and eventually the pantoporate type. Accordingly, Martin (2001) found that most species studied based on fossil and modern pollen features in the family Convolvulaceae in Australia, produced similar appearance of pictures. Further examination of exine structure also confirmed that tricolpate type was recorded to have spherical to prolate grain. Meanwhile, the size of pollen grain was also recorded to have a big size similar to our results.

The morphological complexity of ten Ipomea batatas cultivars particularly the leaf and tuber features were not shown by the pollen morphology. This pollen characters could not be used to explain why do morphological variations of sweet potatoes were not in accordance with the pollen features. This may be one to the fact that not all pollen features were considered to be relevant in taxonomies point of view (Telleria and Daners 2003). The only exine structure and sculpture were noted to have uniform features particularly in the genera levels of Convolaceae (Azzay 2011; Gunes 2012). Thus, it was not surprising that this study did not become apparent, because the plant samples were in the variety level. The only possible reason for the size and aperture variation may be caused by both environmental and genetic influences (Thanikaimoni 1986; Zhao et al. 2016). Therefore, the morphological complexity of ten cultivars sweet potatoes would not be appropriate to relate to their original habitats. Since, all these samples planted at the same environmental condition at research center of Horticultural plants-Malang district (East Java). The variation of morphological complexity of sweet potatoes in this study may be due to genetically induced influences, rather than the environmental factor. This in accordance with the Eserman et al. 2014; that for examining the possible adaptive evolution of morning glories more molecular genetics wee needed to be collected. And this could be observed in transition of flower color from blue to red. This was shown by the unique pattern of both peroxidase isozymes of Beta 1 by presenting the thick band in between $\mathrm{Rf}$ values of 1,13 and 0,26 . The morphological complexity of ten sweet potatoes was not in accordance with the pollen characters, but the use of isozymes data may offer further examination to put better position of these sweet potato cultivars.

In conclusion, the results of this study showed the morphological characters of leaf shapes were the best evidence of variations shown in this sweet potato. This could be shown by the color and Tuber shapes also. Accordingly, this diversity was also manifested by the presence of flower-shaped although the degree was less evidence then the other two morphological characters tested. It is interesting to note that no significant difference of pollen morphological characters of ten sweet potato cultivars tested, but Beta 1 cultivar was found to have unique character, more particularly its very large pollen size, and concave contour of the exine pollen. Moreover, peroxidase isozymes confirmed that the morphological complexity was also expressed by the presence of common bands of each cultivar and unique bands were only expressed at certain cultivars such as Beta 1, Beta 2 and Papua Salosa. This preliminary evidence suggests that isozymes data were in accordance with that of morphological complexity particularly for the lower level taxonomy, but may not suitable for lower level of taxonomy such as variety of plants when the dealing with pollen features. This pollen features may be best to be applied for higher level of taxonomy such as family/genera plant levels.

\section{ACKNOWLEDGEMENTS}

We would like to thank the Head of Research Centre of Horticultural Plants, Malang, Indonesia for providing the sweet potato cultivars. Many thanks also go to Atik and Nina (Molecular Biology Laboratory, Faculty of Mathematics and Natural Sciences, Universitas Sebelas Maret, Surakarta, Indonesian) and technicians of Universitas Negeri Malang (UM), Indonesia for their truly help during electrophoretic experiment of peroxidase isozyme assay. We also highly appreciated all technicians of scanning Electron Microscopy at UM for their friendly support during pollen observation.

\section{REFERENCE}

Adekanmbi OH 2009. Pollen grains of Asteraceae and analogous echinate grains. Intl J Bot 5 (4): 295-300

Agashe SN, Caulton E. 2009. Pollen and Spores: Applications with Special Emphasis on Aerobiology and Allergy. Science Publishers, USA.

Agrios GN. 2005. Plant Pathology. 5th ed. Academic Press, San Diego, CA.

Arrijani. 2003. Kekerabatan fenetik anggota marga Knema, Horsfieldia, dan Myristica di Jawa berdasarkan bukti morfologi serbuk sari. Biodiversitas 4 (2): 83-88. [Indonesian]

Away AK, Nawiri MP, Nyambaka HN. 2013. Nutrient variation in coloured varieties of Ipomoea batatas grown in Vihiga Country. Western Kenya. Intl Food Res J 20 (2): 819-825.

Azzazy MF. 2011. Morphological studies of the pollen grains of Wadi ElNatrun plants, West Nile Delta, Egypt. Plant Syst Evol 294 (3-4): 239-251.

Balitkabi [Balai Penelitian Tanaman Kacang-kacangan dan Umbi-umbian] 2012. Diskripsi Varietas Unggul Kacang-kacangan dan Umbiumbian. Balitbang Pertanian, Kementerian Pertanian, Jakarta. [Indonesian]

Budoyo S. 2010.Carbohydrates Content and Isozyme Ribbon Pattern isozyme in Local Varietyof Sweet Coconut (Dioscorea alata) in Karanganyar. [Thesis]. Universitas Sebelas Maret, Surakarta. [Indonesian]

Cahyarini RD, Yunus A, Purwanto E. 2004. Genetic diversity identification some local varieties of soybean in Java based on isozyme analysis. Agrosains 6 (2): 79-83.

Cheng FR, Staples G. 1995. Convolvulaceae. Flora of China 16: 271-325.

Diao M, Ayékoué BN, Crepin ID, Soumaila D, Mamaoudou D. 2014 Purification and characterization of sweet potato (Ipomoea batatas) peroxidase. J Anim Plant Sci 22 (2): 3419-3432. 
Eserman LA, Tiley GP, Jarnet RL, Leebens Mack JH, Millers RE. 2014. Phylogenetics and diversification pf morning glories (Tribe Ipomoeaceae, Convolvulaceae) based on whole plastome sequences. Amer J Bot 10 (1): 92-102.

Guine F. 2012. Pollen morphology of Lathyrus (Leguminosae) taxa belonging to Lathyrus orbastrum and Cicercula section from Turkey. Plant Syst Evol 298: 1777-1794)

Kodela PG. 2006. Pollen morphology of some rainforest taxa occurring in the Illawara Region of New South Wales, Australia. Teloped 11 (3) 346-389.

Lashin GMA. 2011. Ultrastructures and Pollen Morphology Significance of Some Species of Solanum (Solanaceae). Indian J Fundament Appl Life Sci 1 (1): 11-15.

Tidke JA, Rajurkar AV, Dhawak VR. 2012. Scanning electron microscopic studies on pollen morphology of Bauhinia (Caesalpiniaceae). Indian J Fundament Appl Life Sci 2 (1): 145-151.

Ginting E, Utomo JS, Richana N. 2012. Keunggulan fungsional ubi jalar dari aspek kesehatan. Wargiono (ed). Proeding Ubijalar: Inovasi Teknologi dan Prospek Pengembangan. Pusat Penelitian dan Pengembangan Tanaman Pangan, Bogor. [Indonesian]

Hadiati S, Sukmadjaya D. 2002. Keragaman pola pita beberapa aksesi nenas berdasarkan analisis isozim. Jurnal Bioteknologi Pertanian 7 (2): 62-70. [Indonesian]

Hengky N. 1995. Keragaman pola pita isozim pada empat kultivar kelapa Zuriat 6 (1): 17-24. [Indonesian]

Hidayati NR, Suranto, Sajidan. 2018. Morphological characteristics and isozymes banding patterns of Cucurbita moschata at differen altitudes. Biodiversitas 19 (5): 1683-1689.

Jamshidi S, Samira J. 2011. NTSYSpc 2.02 Implementation in molecular biodata analysis (clustering, screening, and individual selection) International Conference on Environmental and Computer Science IPCBEE 19: 165-169.

Kim YH, Lee HS, Kwak SS. 2010. Differential responses of sweet potato peroxidases to heavy metals. Chemosphere. 81 (1): 79-85.

Li P, Yunwen W, Xiaolong S, Jianguo H. 2009. Using microsatellite (SSR) and morphological markers to assess the genetic diversity of 12 Falcata (Medicagosativa spp. falcata) populations from Eurasia. Afr J Biotechnol 8 (10): 2012-2018.

Martin HA. 2001. The family Convolvulaceae in the Tertiary of Australia: evidence from pollen. Austr J Bot 49: 221-234.

Mills AK, Crowden RK. 1968. Distribution of soluble proteins an enzyme during early development of Pisum sativum. Aust J Biol Sci 21: 1131-1141

Manrique I, Roca W. 2007. Potential of sweet potato (Ipomoea batatas) biodiversity as a functional food in the tropics. Workshop "Functional Foods and Medicinal Products Developments from Amazonian Crops”. Eulaff Embrapa Workshop Rio de Janeiro, Brazil.

Pitoyo A, Prameta AR, Marsusi, Suratman, Suranto. 2018. Morphological, anatomical and isozyme variability among taro accessions from southeastern part of Central Java, Indonesia. Biodiversitas 19 (5) 1811-1819.

Purnobasuki H, Etik P, Thin S. 2014. Keanekaragaman morfologi serbuk sari pada 5 species Bougainvillea. Bioscientiae 11 (1): 48-59. [Indonesian]

Rahayu S, Sumitro, Susilowati T, Soemarmo. 2006. Analisis isozim untuk mempelajari variasi genetik Sapi Bali di Provinsi Bali. Berkas Penelitian Hayati: 12 (1-5). [Indonesian]

Rajurkar AV, Tidke JA, Patil GV. 2011. Studies on pollen morphology of Ipomea species (Convolvulaceae). Res Plant Biol 1 (5): 41-47.

Rose IM, Vasanthakaalam H. 2011. Comparison of nutrient composition of four sweet potato varieties cultivated in Rwanda. Amer J Food Nutr 1 (1): 34-38
Sahu PK, Gupta S. 2014. Medicinal plants of morning glory: Convolvulaceae Juss of Central India (Madhya Pradesh \& Chhattishgarh). Biolife 2 (2): 463-469

Sengupta S. 1972. On the pollen morphology of Convolvulaceae with special reference to taxonomy. Rev Palaeobot Palynol 13: 157-212.

Smith SD, Miller RE, Otto SP. 2010. The effects of flower color transitions on diversification rates in morning glories (Ipomoea subg. Quamoclit, Convolvulaceae). Proceeding of the Darwin 200 Beijing International Conference. Higher Education Press, Beijing, China

Souza IRPD, Oliveira ED, Peres MA, Oliverisa ACD, Pureino AAC. 2003. Peroxidase activity in maize inbred lines resistant or susceptible to maize dwarf mosaic virus. Rev. Brasil Milho Sorgo 2 (1): 1-8.

Suda I, Tomoyuki O, Mami M, Mio K, Yoichi N, Shu F. 2003. Physiological functionality of purple-fleshed sweet potatoes containing anthocyanins and their utilization foods. Japan Agric Res Quart 37 (3): 167-173.

Supadmi S. 2009. Studies of Ipomea batatas L Variation based on Sugar Reduction and Isozyme Banding Pattern. [Thesis]. Universitas Sebelas Maret, Surakarta. [Indonesian]

Suranto. 2001. Isozyme studies on the morphological variation of Ranunculus nanus population. Agrivita 23 (2): 139-146.

Suranto, Arief A, Supyani. 2017. The use of electrophoretic isozymes to detect tungro infected rice. Agrivita 39 (2): 145-152.

Suratman, Priyanto D, Setyawan AD. 2000. Analisis keragaman Genus Ipomoea berdasarkan karakter morfologi. Biodiversitas 1 (2): 72-79. [Indonesian]

Telleria MC, Daners G. 2003. Pollen types in southern new world Convolvulaceae and their taxonomic significance. Plant Syst Evol 243: 99-118

Thanikaimoni G. 1986. Pollen apertures: form and function. In: Blackmore S, Ferguson IK (eds.). Pollen and Spores: Form and Function. Academic Press, New York

Todaria NP, Nautiyal AR, Semival JK. 1983. Electrophoretic protein profile of nodulated and non-nodulated Cassia species in relation to taxonomy. Biochem Syst Ecol 2 (3): 217-219.

Tsakama M, Mwangwela AM, Manani AM, Mahungu NM. 2010. Physicochemical and pasting properties of starch extracted from eleven sweet potato varieties. African J Food Sci Technol 1 (4): 90-98

Truong VD, Mcfeeters RF, Thompson RT, Dean LL, Shofran B. 2007. Phenolic acid content and composition in leaves and roots of common commercial sweet potato (Ipomoea batatas L.) cultivars in the United States. J Food Sci 72 (6): 343-349.

Veasey EA, de Queiroz Silva JR, Rosa MS; Borges A, de Andrade Bressan E, Peroni N. 2007. Phenology and morphological diversity of sweet potato (Ipomoea batatas) landraces of the Vale do Ribeira. Sci Agric (Piracicaba, Braz.) 64 (4): 416-427.

Wahyuni S, Wargiono. 2012. Morphology and anatomy of plant. In: Wargiono (ed.). Sweet Potato: Innovation Technology and its Prospect Development. Centre of Research and Development of Food Crop, Bogor.

Widiyanti, Suranto, Sugiyarto. 2008. Studies on the variation of seed morphology, pollen features and isozyme banding pattern of local variety of Oryza sativa (Raja lele). Bioteknologi 5 (1): 18-25. [Indonesian]

Wilson JE. 1988. Sweetpotato (Ipomoea batatas) Planting Material. AgroFact. IRETA Publication No. 2/88.

Yanti Y. 2011. Aktivitas peroksidase mutan pisang kepok dengan Ethyl Methane Sulphonate (EMS) secara in vitro. Jurnal Nature Indonesia 14 (1): 32-36. [Indonesian]

Zhao X-L, Gao X-F, Bo Xu. 2016. Pollen Morphology of Indigofera (Fabaceae) in China and its taxonomic implication. Plant Syst Evol. 302: 469-479. 